Jurnal Adat dan Budaya, Vol.2, No.2 Tahun 2020

ISSN: E-ISSN 2615-6156, P-ISSN: 2615-6113

Jurnal Homepage: https://ejournal.undiksha.ac.id/index.php/JABI/index

\title{
MODEL PEMBELAJARAN PAIR CHECKS BERBASIS TAT TWAM ASI TERHADAP KOMPETENSI PENGETAHUAN PPKn SISWA
}

\author{
I Made Wahyu Adi Sanjaya 1, I Gusti Ayu Agung Sri Asri², Ni Wayan Suniasih ${ }^{3}$ \\ 123 Prodi Pendidikan Guru Sekolah Dasar, Universitas Pendidikan Ganesha, Bali, Indonesia \\ E-mail: made.wahyu.adsanjaya1@undiksha.ac.id
}

\begin{abstract}
Abstrak
Berdasarkan permasalahan yang ditemui yaitu rendahnya kompetensi pengetahuan PPKn siswa, penelitian ini bertujuan untuk mengkomunikasikan pengaruh yang signifikan model pembelajaran Pair Checks berbasis Tat Twam Asi terhadap kompetensi pengetahuan PPKn. Penelitian ini merupakan penelitian quasi eksperimen dan menggunakan desain penelitian Non-equivalent Control Group Design. Sampel dalam penelitian ini terdiri dari dua kelas dengan jumlah siswa 62 orang yaitu kelompok eksperimen dengan jumlah 30 orang siswa dan kelompok kontrol dengan jumlah siswa 32 orang Pemilihan sampel dalam penelitian ini menggunakan cluster random sampling. Data kompetensi pengetahuan PPKn siswa dikumpulkan menggunakan metode tes, dengan jenis tes yang digunakan adalah tes pilihan ganda biasa yang kemudian dianalisis menggunakan uji-t. Hasil penelitian menunjukkan nilai rata-rata kelompok eksperimen lebih tinggi daripada nilai rata-rata kelompok kontrol $(\overline{\boldsymbol{X}}=79,56>\overline{\boldsymbol{X}}=$ 72,08). Berdasarkan hasil analisis uji-t dengan derajat kebebasan $(\mathrm{dk}=30+32-2=60)$ dan pada taraf signifikan $5 \%$ diperoleh $t_{\text {hitung }}>t_{\text {tabel }}(3,113>2,000)$ maka $\mathrm{H}_{0}$ ditolak dan $\mathrm{H}_{\mathrm{a}}$ diterima. Dengan demikian dapat disimpulkan, bahwa model pembelajaran Pair Checks berbasis Tat Twam Asi berpengaruh terhadap kompetensi pengetahuan PPKn.
\end{abstract}

Kata Kunci: Pair Checks; TTA; PPKn

\begin{abstract}
Based on the problems encountered, namely the low competency of students PPKn knowledge, this study aims to communicate the significant influence of Tat Twam Asi based Pair Checks learning model on PPKn knowledge competence. This research is a quasi-experimental study and uses a Non-equivalent Control Group Design research design. The sample in this study consisted of two classes with a total of 62 students, namely the experimental group with a total of 30 students and a control group with a total of 32 students. The sample selection in this study used cluster random sampling. PPKn students' knowledge competency data is collected using the test method, with the type of test used is the usual multiple choice test which is then analyzed using the t-test. The results showed the average value of the experimental group was higher than the average value of the control group $(\overline{\boldsymbol{x}}=79.56>\overline{\boldsymbol{X}}=72.08)$. Based on the results of the t-test analysis with degrees of freedom $(\mathrm{dk}=30+32-2=60)$ and at a significant level of $5 \%$ was obtained $t_{\text {count }}>t_{\text {table }}(3.113>2,000)$ then $\mathrm{H}_{0}$ was rejected and $\mathrm{H}_{\mathrm{a}}$ was accepted. Thus it can be concluded, that the Pair Checks learning model based on Tat Twam Asi influences the knowledge competence of PPKn.
\end{abstract}

Keywords: Pair Checks; TTA; Civic

\section{PENDAHULUAN}

Pendidikan mempunyai peranan yang sangat penting dalam meningkatkan kualitas sumber daya manusia. Pendidikan sangat perlu untuk dikembangkan dari berbagai ilmu pengetahuan karena pendidikan yang berkualitas dapat meningkatkan kecerdasan suatu bangsa. Sumber daya manusia yang berkualitas diharapkan mampu mengadakan perubahan bagi Indonesia ke arah yang lebih baik. Untuk itu, pendidikan memegang peran penting dalam usaha menyiapkan Sumber daya manusia yang berkualitas. "Pendidikan bagi kehidupan umat manusia merupakan kebutuhan mutlak yang harus dipenuhi sepanjang hayat. Manusia, mustahil dapat berkembang sejalan dengan aspirasi (cita-cita) untuk maju, sejahtera dan bahagia tanpa adanya pendidikan" (Ibrahim, 2017). Maka, kita sebagai warga negara harus berhasil dalam membangun dasar-dasar pendidikan nasional, dan diharapkan bisa memberikan kontribusi kemajuan di bidang lainnya. 
Berdasarkan Undang- Undang Sitem Pendidikan Nasional Nomor 20 tahun 2003 menyatakan bahwa Pendidikan Nasional berfungsi mengembangkan kemampuan dan membentuk watak serta peradaban bangsa yang bermartabat dalam rangka mencerdaskan kehidupan bangsa, dalam berkembangnya potensi siswa agar menjadi manusia yang beriman dan bertakwa kepada Tuhan Yang Maha Esa, berakhlak mulia, sehat, berilmu, cakap, kreatif, mandiri, dan menjadi warga Negara yang demokratis serta bertanggung jawab. Pendidikan merupakan peranan yang sangat besar dalam maju mundurnya suatu bangsa. Melalui pendidikan juga akan melahirkan peserta didik yang cerdas serta mempunyai kompetensi dan skill untuk dikembangkan ditengah-tengah masyarakat (Mardika, 2017). Faktor proses pembelajaran di sekolah berjalan dengan baik karena adanya guru, dan keberhasilan dalam proses pembelajaran agar anak didik dapat mengubah perilakunya juga merupakan faktor dari guru tersebut. Untuk mencapai hal tersebut, perlu adanya paradigma baru dalam proses pembelajaran, dari yang awalnya pembelajaran berpusat kepada guru menjadi berpusat kepada siswa agar mereka mampu mengembangkan potensi yang dimilikinya. Perubahan yang dilakukan antara lain dari segi kurikulum, model pembelajaran, dan cara mengajar.

Peraturan Menteri Pendidikan dan Kebudayaan Republik Indonesia Nomor 35 Tahun 2018 tentang Perubahan atas Peraturan Menteri Pendidikan dan Kebudayaan menyebutkan bahwa "kurikulum adalah seperangkat rencana dan pengaturan mengenai tujuan, isi, dan bahan pelajaran serta cara yang digunakan sebagai pedoman penyelenggaraan kegiatan pembelajaran untuk mencapai tujuan pendidikan tertentu. Berdasarkan pengertian tersebut, ada dua dimensi kurikulum, yang pertama adalah rencana dan pengaturan mengenai tujuan, isi, dan bahan pelajaran, sedangkan yang kedua adalah cara yang digunakan untuk kegiatan pembelajaran". Kurikulum merupakan sejumlah rencana isi yang merupakan sejumlah tahapan belajar yang didesain untuk siswa dengan petunjuk intitusi pendidikan yang isinya berupa proses yang statis ataupun dinamis dan kompetensi yang harus dimiliki. Kurikulum merupakan salah satu faktor penting di bidang pendidikan karena dapat memberikan konstribusi yang signifikan untuk mewujudkan proses berkembangnya potensi peserta didik, karena kuikulum berisi rancangan pendidikan yang memberikan kesempatan untuk peserta didik mengembangkan potensi dirinya dalam suatu kondisi belajar yang menyenangkan dan sesuai dengan kemampuan dirinya (Ahmad, 2016). Diharapkan dengan adanya perubahan kurikulum pendidikan di Indonesia berkembang untuk membentuk sumber daya manusia yang mampu bersaing di dunia global. Kurikulum 2013 lebih menekankan pada dimensi pedagogik modern yaitu dengan pendekatan ilmiah (scientific). Pendekatan saintifik dimaksud untuk memberikan pemahaman kepada peserta didik dalam mengenal, memahami berbagai materi menggunakan pendekatan ilmiah, bahwa informasi bisa berasal dari mana saja, kapan saja, tidak bergantung pada informasi searah guru oleh karena itu kondisi pembelajaran yang diharapkan tercipta diarahkan untuk mendorong peserta didik dalam mencari tahu dari berbagai sumber melalui observasi, dan bukan hanya diberi tahu (Selly Lindayani, 2019).

Kurikulum 2013 juga menekankan siswa untuk dapat berpikir tingkat tinggi (HOTS). Higher Order Thinking Skill (HOTS) atau kemampuan berpikir tingkat tinggi adalah proses berpikir yang mengharuskan siswa untuk memanipulasi informasi yang ada ide-ide dengan cara tertentu yang memberikan mereka pengertian dan implikasi baru (Arni Rahayuni, 2018). Pembelajaran Kurikulum 2013 tidak hanya menekankan pencapaian kompetensi pengetahuan melainkan menekankan nilai-nilai yang tercermin pada sikap yang dapat berbanding lurus dengan keterampilan yang diperoleh peserta didik melalui pengetahuan dibangku sekolah. Sekolah memegang peranan penting dalam mengembangkan kemampuan kognitif, afektif, dan psikomotor siswa." Selain penilaian sikap dan keterampilan, Kemampuan kognitif juga perlu ditingkatkan, supaya memperoleh hasil belajar yang sesuai dengan Kriteria Ketuntasan Minimum (Yulia Citra, 2018). Kunandar, (2015:165) menyatakan bahwa "penilaian kompetensi pengetahuan atau kognitif adalah penilaian yang dilakukan guru untuk mengukur tingkat pencapaian atau penguasaan peserta didik dalam aspek pengetahuan yang meliputi ingatan atau hafalan, pemahaman, penerapan atau aplikasi, analisis, sintesis, dan evaluasi".

Jadi, antara soft skills dan hard skills dapat tertanam secara seimbang. Pembelajaran pada Kurikulum 2013 adalah pembelajaran tematik terpadu, yakni pembelajaran yang 
menggabungkan beberapa mata pelajaran ke dalam sebuah tema. PPKn merupakan salah satu muatan materi yang wajib dibelajarkan kepada siswa di jenjang Sekolah Dasar sampai dengan Perguruan Tinggi. Pendidikan Kewarganegaraan (PKn) pada dasarnya adalah belajar tentang Indonesia, belajar untuk menjadi manusia yang berkepribadian Indonesia, membangun rasa kebangsaan, dan mencintai tanah air Indonesia (Prakoso, 2015). Pendidikan kewarganegaraan dimaksudkan untuk membentuk peserta didik menjadi manusia yang memiliki rasa kebangsaan dan cinta tanah air. (Undang-Undang RI No 20 Tahun 2003, Penjelasan Pasal 37). Pernyataan tersebut diharapkan dengan pembelajaran Pendidikan Kewarganegaraan mampu mendidik peserta didik yang cinta tanah air, berwawasan nusantara, mengembangkan sikap dan moral yang berlandasakan Pancasila yang akan didapatkan generasi yang menjaga keutuhan dan persatuan bangsa Pendidikan Pancasila dan Kewarganegaraan merupakan pendidikan yang berlandaskan demokrasi dengan tujuan mempersiapkan masyarakat agar mampu berpikir kritis dan bertindak demokratis dengan cara menanamkan kesadaran kepada generasi baru bahwa demokrasi yang menjamin hak-hak warga masyarakat. Tujuan PKn di sekolah dasar untuk menjadikan warga negara yang baik, yaitu warga negara yang tahu, mau, dan sadar akan hak dan kewajibannya sehingga nantinya akan menjadi warga yang baik (Susanto, 2013). Pendidikan Pancasila dan Kewarganegaraan adalah pembentukan individu agar dapat mendukung dan memperkuat komunitas politik yang merupakan hasil kesepakatan (Ermavianti \& Sulistyorini, 2016). Pendidikan Pancasila dan Kewarganegaraan (PPKn) diharapkan mampu membentuk peserta didik agar memiliki sikap tanggung jawab dalam bermasyarakat dan bernegara, memiliki rasa cinta tanah air, berwawasan nusantara, mengembangkan sikap dan moral yang berlandaskan Pancasila.

Berdasarkan observasi penelitian yang dilakukan di kelas V SDN di Gugus I Kecamatan Selat, Kabupaten Karangasem banyak siswa yang kurang berpartisipasi aktif dalam mengikuti pembelajaran PPKn dan kompetensi pengetahuan siswa yang diperoleh sebagian besar masih rendah terlihat dari 212 siswa terdapat 63 siswa atau 32\% masih belum mencapai KKM. Berkaitan dengan hal tersebut dikarenakan sebagian besar kurangnya variasi model pembelajaran yang digunakan di dalam kelas sehingga siswa kurang aktif di dalam kelas. Saat siswa menjawab pertanyaan guru, kurangnya kesadaran dalam menghargai teman saat berbicara di depan kelas dan saat menjawab pertanyaan guru, karena siswa merasa malu, takut untuk mengutarakan pendapatnya, dan merasa tidak digargai saat berbicara oleh beberapa temannya. Mata pelajaran PPKn dianggap sebagai salah satu mata pelajaran yang membosankan bagi siswa. Kondisi demikian apabila dibiarkan akan berdampak negatif terhadap kualitas pembelajaran PPKn terhadap siswa. Dampaknya kepada siswa, nilai akan menurun, kurangnya semangat dalam mengikuti pembelajaran di kelas, sikap saling menghargai antar siswa semakin menurun. Maka sangat penting bagi guru untuk menerapkan model pembelajaran yang bervariasi untuk meningkatkan prestasi belajar siswa maka guru dituntut untuk membuat pembelajaran lebih inovatif yang mendorong siswa dapat belajar secara optimal dan berpatisipasi secara aktif dalam proses pembelajaran. Dalam pemilihan model pembelajaran yang tepat guru perlu mengetahui karakteristik siswa, materi pembelajaran, tujuan pembelajaran, dan kondisi lingkungan pada saat ini. (Erman, 2008). Hal itulah yang mengharuskan guru memahami model - model pembelajaran dan menyesuaikan dengan keadaan siswa agar kompetensi pengetahuan yang di harapkan bisa tercapai dan pola belajar siswa yang sesuai dengan kondisi yang dialami oleh siswa dan kurikulum yang diterapkan saat ini.

(Bagja \& Yuliana, 2019) menyatakan bahwa "model pembelajaran adalah salah satu cara yang dipergunakan guru dalam menyampaikan materi kepada siswa dengan maksud untuk mencapai tujuan belajar yang disepakati". Mewujudkan peserta didik yang diharapkan, maka sangat penting bagi guru untuk meningkatkan perubahan kemampuan inovasi dalam proses pembelajaran yang dapat menciptakan pembelajaran yang bermakna dan menyenangkan (Ananda, 2018). Model pembelajaran yang dapat merangsang keaktifan siswa yaitu model pembelajaran kooperatif yang melibatkan peran dan partisipasi aktif dalam masing-masing anggota kelompok. Salah satu model pembelajaran yang bisa meningkatkan keaktifan siswa adalah model pembelajaran kooperatif tipe Pair Checks. Model Pair Checks yaitu model 
pembelajaran yang menyelesaikan persoalan dengan cara siswa saling berpasangan (Herdian (dalam Shoimin), 2014). Model ini merupakan proses belajar yang mengutamakan kerja sama kelompok, yang setiap anggota kelompoknya harus memiliki sikap mandiri dan dapat menyelesaikan persoalan yang diberikan dan model ini bertujuan untuk meningkatkan kemampuan siswa dalam menuangkan ide, pikiran, pengalaman, dan pendapatnya dengan benar. Dalam model pembelajaran kooperatif tipe Pair Checks, guru sebagai motivator dan fasilitator. Di dalam pembelajaran kooperatif tipe Pair-Checks ini menggunakan kelompokkelompok yang terdiri dari 4 orang siswa yang dipilih secara heterogen berdasarkan kemampuan akademik siswa. Dengan pembagian kelompok seperti ini diharapkan terjadi keseimbangan di dalam tiap kelompok, di mana peserta didik yang berkemampuan tinggi dapat saling membantu peserta didik lain yang berkemampuan rendah, yang nantinya guru sebagai pendidik juga akan membantu membimbing siswa di dalam kelompok.

Sintak model pembelajaran Pair-Checks ini pertama guru membentuk kelompok menjadi 4 orang siswa. Setelah guru membentuk kelompok, kemudian dari kelompok tersebut dipecahkan lagi menjadi pasangan-pasangan. Satu kelompok terdiri atas dua pasangan. Setiap pasangan memiliki peran masingmasing. Ada yang berperan menjadi partner atau yang mengerjakan soal dan ada yang berperan menjadi coach atau yang menjadi pelatih yang membantu dan mengoreksi hasil pekerjaan partner. Setiap partner dalam kelompok diberikan kesempatan terlebih dahulu oleh guru untuk mengerjakan soal yang disajikan. Sementara coach, membantu dan mengoreksi pekerjaan si partner. Guru memberikan coach kunci jawaban untuk mengoreksi pekerjaan si partner dan coach juga menjelaskan kepada si partner di mana letak kesalahan si partner seandainya jawaban si partner ada yang salah. Setelah partner menyelesaikan tugasnya dan coach mengoreksi jawaban si partner, kemudian antara si partner dan coach bergantian peran. Partner menjadi coach, dan coach menjadi partner. Kemudian, pasangan-pasangan tersebut kembali ke kelompok asal, dan mendiskusikan jawaban yang telah diselesaikan. Setelah itu, masing-masing pasangan dalam kelompok tersebut memberikan nilai terhadap hasil pekerjaan pasangannya. Guru memberikan reward kepada kelompok yang berhasil mengerjakan tugas yang diberikan dengan benar. Dengan adanya sebuah reward 4 akan lebih memotivasi siswa, mereka yang ingin mendapatkan reward tersebut maka harus saling membantu antar kelompok masing-masing. Model pembelajaran ini lebih mefokuskan pada aktifitas belajar siswa karena siswa bukan sebagai objek, tetapi sebagai subjek dalam kegiatan pembelajaran yang perlu dikembangkan pengalaman belajarnya (Kristin, 2016). Model ini memiliki beberapa keunggulan yakni menurut Puspita (2018) beberapa keunggulan dari model Pair Checks antara lain memandu siswa belajar melalui bantuan rekan-rekan temannya, menciptakan saling kerja sama diantara siswa, meningkatkan pemahaman atas konsep proses pembelajaran siswa dan melatih siswa berkomunikasi dengan baik dengan teman sebangku.

Model ini merupakan proses belajar yang mementingkan kerja sama kelompok, maka setiap anggota harus mempunyai sikap mandiri dan mampu menyelesaikan persoalan yang telah diberikan. Selain itu, model ini juga dapat melatih rasa sosial siswa, dan kemampuan memberi penilaian kepada temannya pada saat proses pembelajaran. Model pembelajaran Pair Checks mengutamakan teknik berpasang-pasangan, yaitu salah seorang memberikan sebuah persoalan dan temannya mengerjakan, kebenaran jawaban akan di cek melalui bertukar peran. Pembagian kelompok siswa secara berpasangan menunjukkan pencapaian yang jauh lebih besar dalam bidang ilmu (Susanto, 2012). Model ini memiliki tujuan untuk dapat meningkatkan kemampuan siswa dalam menuangkan ide, pikiran, pengalaman, dan pendapatnya dengan benar. Strategi Pair Checks membuat siswa agar saling berpendapat dan saling memberi saran.

Selain pemilihan model pembelajaran yang tepat, untuk menumbuhkan nilai kesadaran, moral dan karakter pada siswa saat pembelajaran maka perlu suatu inovasi dalam pelaksanaan pembelajaran PPKn yaitu model pembelajaran yang berbasis Tat Twam Asi. (Wesi Kusuma, 2018) menyatakan melalui pembelajaran nilai-nilai luhur dalam masyarakat, siswa mengetahui landasan dalam berperilaku di masyarakat serta membantu membentuk karakter siswa, banyak hal yang dapat dijadikan bahasa dalam pembelajaran salah satunya budaya masyarakat setempat dapat dijadikan sebagai alat bantu dalam proses pemahaman materi. Sesuai dengan pernyataan tersebut salah satunya yaitu Tat Twam Asi. Tat Twam Asi adalah salah satu filsafat 
Hindu yang mengajarkan tentang bagaimana menghargai sesama makhluk ciptaan Tuhan Yang Maha Esa. Tat Twan Asi artinya aku adalah kamu, kamu adalah aku, yang bemakna tidak boleh saling menyakiti segala makhluk karena semua sama sehingga menyakiti orang lain sama berarti manyakiti diri sendiri dan menolong orang lain berarti menolong diri sendiri (Sumarni, 2014). Oleh karena itu, sudah tentu kita dilarang untuk menyakiti sesama mahluk ciptaan-Nya. Dalam proses pembelajaran di kelas, menjaga hubungan baik antar sesama bisa dilakukan dengan belajar bersama, saling membantu dalam proses pembelajaran. Berdasarkan urain di atas, model pembelajaran Pair Checks berbasis Tat Twam Asi berpengaruh terhadap kompetensi pengetahuan PPkn, pernyataan ini didukung oleh dua peneliti, menurut (Miswandi, 2018) “ model pembelajaran Pair Check digunakan untuk mencari adanya pengaruh terhadap kompetensi pengetahuan PPKn siswa". Hal ini dibuktikan dengan $t_{\text {hitung }}>t_{\text {tabel }}$ diperoleh rata-rata hasil kompetensi pengetahuan PPKn siswa kelompok eksperimen lebih tinggi dari kelompok kontrol yaitu 3,870 > 2,000. Kemudian menurut (Handayani \& Yanti, 2017) "pembelajaran berbasis Tat Twam Asi dalam proses pembelajaran dapat mendorong siswa untuk saling menghargai, bertoleransi dan saling membantu satu sama lain sehingga berpengaruh terhadap kompetensi pengetahuan siswa". Hal ini dibuktikan dengan $t_{\text {hitung }}>t_{\text {tabel }}$ diperoleh penguasaan kompetensi pengetahuan siswa kelompok eksperimen lebih tinggi dari kelompok kontrol yaitu $2,30>2,000$. Berdasarkan pemaparan tersebut, sehingga perlu dilaksanakan penelitian yang berjudul berjudul "Pengaruh model pembelajaran Pair Checks berbasis Tat Twan Asi terhadap kompetensi pengetahuan PPKn siswa kelas V SDN Gugus I Kecamatan Selat Tahun Pelajaran 2019/2020".

\section{METODE}

Penelitian ini dilaksanakan untuk mengetahui pengaruh dari perlakuan tertentu, sehingga metode penelitian yang digunkan adalah metode penelitian eksperimen yang termasuk ke dalam jenis penelitian kuantitatif. (Sugiono, 2016), menyatakan "metode eksperimen nerupakan metode penelitian yang digunakan untuk mencari tahu pengaruh perlakuan tertentu terhadap yang lain dalam kondisi yang terkendalikan". Penelitian ini dilaksanakan pada semester II di SDN Gugus I Kecamatan Selat. Adapun sekolah yang digunakan dalam penelitian ini yaitu SD Negeri 1 Duda Timur yang beralamat di Banjar Wates Kangin, Duda Timur, Kec.Selat, Kab. Karangasem sebagai kelas eksperimen dan SD Negeri 3 Duda yang beralamat di Banjar Jangu, Duda, Kecamatan Selat, Kabupaten Karangasem sebagai kelas kontrol. Rancangan penelitian yang digunakan yaitu penelitian eksperimen. Jenis penelitian yang dilaksanakan yaitu rancangan eksperimen semu (quasi experimental design) yang dipergunakan yaitu rancangan kelompok non-ekuivalen control group design. Populasi dalam penelitian ini yaitu seluruh kelas $\mathrm{V}$ yang ada di SDN Gugus I Kecamatan Selat yang terdiri atas 7 kelas dari 7 sekolah dengan total keseluruhan siswa berjumlah 212 siswa. Dari populasi tersebut dapat diambil sampel yang mewakili karakteristik dari populasi yang ditelliti. Pada penentuan sampel, dapat digunakan cara yaitu dengan teknik sampling. Teknik sampling yang digunakan yaitu random sampling. Pada penentuan sampel menggunakan cara pengundian yang dilakukan dengan menulis semua kelas V di seluruh SDN populasi dengan jumlah 7 kertas dan kemudian kertas digulung. Lakukan pengundian agar mendapatkan dua kelas. Kelas yang diperoleh dari hasil pengundian yaitu kelas V SD Negeri 1 Duda Timur dan kelas V SD Negeri 3 Duda kemudian diberikan pre test. Pretest yang diberikan untuk menyetarakan kelompok. Penyetaraan kelompok dilakukan dengan uji-t setelah melewati uji normalitas dan uji homogenitas. Akan tetapi, sebelum dilakukan penyetaraan menggunakan uji-t, dilakukan uji prasyarat analisis yaitu uji normalitas dan uji homogenitas varian. Jika skor hasil pre-test sudah memenuhi prasyarat maka dianalisis menggunakan uji-t dengan rumus polled varians dengan kriteria kelompok dinyatakan setara pada taraf signifikansi $5 \%$ dan $d k=n 1+n 2-2$ pada kriteria apabila $t_{\text {hitung }} \leq t_{\text {tabel }}$ sehingga $\mathrm{H}_{0}$ diterima. Sebaliknya apabila kelompok dinyatakan tidak setara apabila $t_{\text {hitung }}>t_{\text {tabel }}$ sehingga $\mathrm{H}_{0}$ ditolak. Jika data sudah dikatakan setara, maka dilakukan pengundian untuk menentukan kelas eksperimen dan kontrol. Hasil pengundian yaitu kelas V SD Negeri 1 Duda Timur dengan jumlah siswa 32 orang sebagai kelas eksperimen yang dibelajarkan dengan model Pair Checks berbasis 
Tat Twam Asi dan kelas V SD Negeri 3 Duda dengan jumlah siswa 30 orang sebagai kelas kontrol yang dibelajarkan dengan pembelajaran konvensional.

Cara atau teknik yang dilakukan untuk mengumpulkan data dalam penelitian yaitu menggunakan metode pengumpulan data. Metode yang digunakan dalam penelitian ini yaitu metode tes obyektif dalam bentuk pilihan ganda dengan empat pilihan. Pada penelitian ini digunakan instrumen mengumpulkan data kompetensi pengetahuan PPKn adalah tes. Dalam penyusunan instrumen, terlebih dahulu dibuat kisi-kisi. Kisi-kisi kompetensi pengetahuan PPKn dibuat dengan berpedoman pada landasan kurikulum yang ada yakni Kurikulum 2013 menyangkut kompetensi inti, kompetensi dasar, aspek materi dan indikatornya. Menurut Arikunto (2015) tes pilihan ganda yakni tes yang terdiri dari bagian keterangan dan bagian kemungkinan jawaban (options). Kemungkinan jawaban terdiri atas satu jawaban yang benar yaitu kunci jawaban dan beberapa pengecoh (distractor). Namun, sebelum tes diberikan kepada siswa, perlu diuji kelayakan pada instrumen tersebut dengan melakukan validasi instrument meliputi validitas isi dan validitas butir tes, uji daya beda, tingkat kesukaran dan reliabilitas.

Langkah selanjutnya bila data sudah terkumpul, data tersebut perlu dianalisis. Penggunaan analisis pada penelitian ini adalah dengan analisis statistik inferensial. Data yang diperoleh dari hasil pre test maupun post test dianalisis dengan statistik inferensial. Teknik analisis pada penelitian ini menggunakan rumus polled varians yang digunakan pada uji-t yang digunakan pada panelitian ini. Uji Hipotesis dengan uji-t menggunakan rumus polled varians. Sebelum melakukan uji-t terlebih dahulu dilakukan uji prasyarat analisis yaitu uji normalitas sebaran data dan uji homogenitas varians. Uji normalitas sebaran data dihitung dengan menggunakan uji Kolmogorov-Smirnov dengan kriteria pengujian adalah apabila nilai maksimum $\left|\mathrm{F}_{\mathrm{T}}-\mathrm{F}_{\mathrm{S}}\right| \leq$ nilai tabel Kolmogorov-Smirnov, artinya data berdistribusi normal. Sebaliknya jika nilai maksimum $\left|\mathrm{F}_{\mathrm{T}}-\mathrm{F}_{\mathrm{S}}\right|>$ nilai tabel Kolmogorov-Smirnov, maka data tidak berdistribusi normal. Uji homogenitas varians dapat dilakukan dengan uji fisher (uji F) dengan kriteria dalam pengujian ini adalah jika $F_{\text {hitung }} \leq F_{\text {tabel }}$, maka sampel homogen. Sebaliknya jika $F_{\text {hitung }}>F_{\text {tabel }}$, sampel tidak homogen. Pengujian dilakukan pada taraf signifikansi 5\% dengan dk untuk pembilang $\mathrm{n}_{1}-1$ dan untuk penyebut $\mathrm{n}_{2}-1$. Setelah melakukan uji normalitas dan homogenitas, data tersebut akan dilakukan uji hipotesis. Apabila data yang diperoleh sudah memenuhi prasyarat, akan dilakukan analisis menggunakan analisis statistik parametrik. Analisis statistik yang digunakan untuk menguji penelitian ini adalah uji-t polled varians dengan kriteria pengujian, jika $t_{\text {hitung }}<t_{\text {tabel }}$ pada derajat kebebasan $n_{1}+n_{2}-2$ dan taraf signifikasi $=0,05$, maka semua kelas dinyatakan setara.

\section{HASIL DAN PEMBAHASAN}

Data nilai kompetensi pengetahuan PPKn kelompok eksperimen yang diberikan perlakuan dengan diberi kegiatan pelajaran menggunakan model pembelajaran Pair Checks berbasis Tat Twam Asi diperoleh rata-rata (means) sebesar 79,56, standar deviasi sebesar 10,31, varians sebesar 106,31, nilai maksimum sebesar 97, dan nilai minimum sebesar 60 . Sedangkan, data nilai kompetensi pengetahuan PPKn kelompok Kontrol dengan pemberian perlakuan kegiatan belajar menggunakan pembelajaran konvensional. Menurut pemaparan tabel tersebut didapatkan rata-rata (means) sebesar 72,08, standar deviasi sebesar 9,94, varians sebesar 98,78, nilai maksimum sebesar 90, dan nilai minimum sebesar 50 .

Tabel 1. Rekapitulasi Hasil Analisis Post-test Kompetensi Pengetahuan PPKn Statistik Kompetensi Pengetahuan IPA

\begin{tabular}{lcc}
\multicolumn{1}{c}{ Statistik } & \multicolumn{2}{c}{ Kompetensi Pengetahuan IPA } \\
\cline { 2 - 3 } & Kelompok Eksperimen & Kelompok Kontrol \\
\hline Rata-Rata $\bar{X}$ & 79,56 & 72,08 \\
\hline Standar Deviasi $(\mathrm{S})$ & 10,31 & 98,78 \\
\hline Varians $\left(\mathrm{S}^{2}\right)$ & 106,31 & 98,78 \\
\hline Skor Tertinggi & 97 & 90 \\
\hline Skor Terendah & 60 & 50
\end{tabular}


Salah satu uji prasyarat analisis yaitu uji normalitas sebaran data. Uji normalitas dilaksanakan guna mengetahui sebaran data dari skor kompetensi pengetahuan PPKn siswa kelompok eksperimen maupun kontrol berdistribusi normal atau tidak. Uji normalitas sebaran data pada penelitian ini menggunakan uji Kolmogorov-Smirnov, dengan menggunakan taraf signifikansi 5\% yaitu apabila nilai $\mid$ FT - FS $\mid$ terbesar $\leq$ nilai tabel Kolmogorov-Smirnov, oleh karena itu data dapat dinyatakan berdistribusi normal, uji normalitas sebaran data kelompok eksperimen diperoleh harga nilai maksimum $\left|\mathrm{F}_{\mathrm{T}}-\mathrm{F}_{\mathrm{S}}\right|=0,123<$ harga nilai tabel kolmogorovsmirnov $=0,242$, maka sebaran data dari data nilai kompetensi pengetahuan PPKn kelompok eksperimen berdistribusi normal. Pada kelompok kontrol harga nilai maksimum $\left|F_{T}-F_{S}\right|=$ $0,083<$ harga nilai tabel kolmogorov-smirnov $=0,234$, maka sebaran data dari data nilai kompetensi pengetahuan PPKn kelompok kontrol dinyatakan berdistribusi normal. Langkah selanjutnya pada uji prasyarat analisis adalah uji homogenitas varians. Uji homogenitas varians dilakukan terhadap data perolehan dari kedua kelompok. Tujuan dari dilakukannya uji homogenitas varians adalah untuk mengetahui varians homogen atau tidak. Pada uji homogenitas varians dipergunakan rumus yaitu dengan menggunakan uji $F$ (fisher). Berdasarkan hasil perhitungan diperoleh harga $F_{\text {hitung }}=1,08$, angka itu selanjutnya dibandingkan dengan harga $\mathrm{F}_{\text {tabel }}$ dengan taraf signifikansi $5 \%(\alpha=0,05)$ dengan dk untuk pembilang yaitu 32-1 = 31 dan dk untuk penyebut 30-1 = 29, sehingga dapat diperoleh $\mathrm{F}_{\text {tabel }}=$ 1,85, maka dari itu data nilai kompetensi pengetahuan PPKn dari kedua kelas dinyatakan mempunyai varians yang homogen.

\section{Tabel 2. Hasil Uji Normalitas dan Uji Homogenitas Kelompok Eksperimen dan Kelompok Kontrol}

\begin{tabular}{|c|c|c|c|c|c|c|c|c|c|}
\hline No & $\begin{array}{c}\text { Kelompok } \\
\text { Sampel }\end{array}$ & $\begin{array}{l}\text { Jumlah } \\
\text { Sampel }\end{array}$ & $\begin{array}{c}\text { Nilai } \\
\text { Maksimum } \\
\left|F_{\mathrm{T}}-\mathrm{F}_{\mathrm{S}}\right|\end{array}$ & $\begin{array}{l}\text { Nilai Tabel } \\
\text { Kolmogorov- } \\
\text { smirnov }\end{array}$ & Varians & $\mathbf{d k}$ & $\mathbf{F}_{\text {hitung }}$ & $\mathbf{F}_{\text {tabel }}$ & Kesimpulan \\
\hline 1 & $\begin{array}{c}\text { Kelompok } \\
\text { Eksperimen }\end{array}$ & 30 & 0,123 & 0,242 & 106,31 & 31 & & & $\begin{array}{l}\text { Berdistribusi } \\
\text { Normal }\end{array}$ \\
\hline & & & & & & & 1,08 & 1,85 & Homogen \\
\hline 2 & $\begin{array}{l}\text { Kelompok } \\
\text { Kontrol }\end{array}$ & 32 & 0,083 & 0,234 & 98,75 & 29 & & & $\begin{array}{l}\text { Berdistribusi } \\
\text { Normal }\end{array}$ \\
\hline
\end{tabular}

Setelah dilaksanakannya uji normalitas sebaran data maupun uji homogenitas varians diperoleh data yang berasal dari kedua kelompok dinyatakan berdistribusi normal dan mempunyai varians yang homogen. Maka dari itu, diperolehlah data yang sudah memenuhi uji prasyarat analisis, selanjutnya dapat dilaksanakan uji hipotesis yang menggunakan analisis uji-t yang digunakan adalah rumus polled varians.Kriteria pengujian dari uji-t yaitu jika $t_{\text {hitung }} \leq t_{\text {tabel }}$, dinyatakan $\mathrm{H}_{\mathrm{o}}$ diterima. Seandainya jika $t_{\text {hitung }}>\mathrm{t}_{\text {tabel }}$, dinyatakan $\mathrm{H}_{\mathrm{o}}$ ditolak, dengan $\mathrm{dk}=\mathrm{n} 1+\mathrm{n} 2$ - 2 pada taraf signifikansi $5 \%(\alpha=0,05)$.Berdasarkan hasil perhitungan dan tabel rekapitulasi hasil analisis uji-t, didapatkan $t_{\text {hitung }}=3,113$ pada taraf signifikansi $5 \%$ dengan $\mathrm{dk}=(30+32-2)$ $=60$ didapatkan ttabel $=2,000$. Dengan kriteria $t_{\text {hitung }}=3,113>t_{\text {tabel }}=2,000$ oleh karena itu, $H_{o}$ ditolak dan $\mathrm{H}_{\mathrm{a}}$ diterima. Hal ini berartiterdapat perbedaan yang signifikan kompetensi pengetahuan PPKn antara kelompok siswa yang dibelajarkan menggunakan model Pair Checks berbasis Tat Twam Asi dengan kelompok siswa yang dibelajarkan menggunakan pembelajaran konvensional pada siswa kelas V SDN Gugus I Kecamatan Selat Tahun Pelajaran 2019/2020.

\section{Tabel 3. Uji Hipotesis}

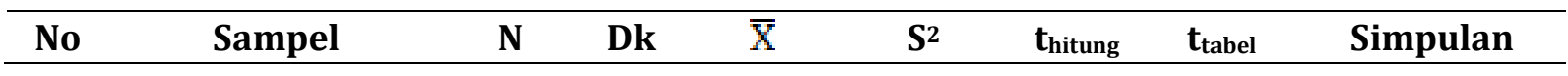




\begin{tabular}{lcccccccc}
\hline 1 & Kelas Eksperimen & 30 & \multirow{2}{*}{60} & $\begin{array}{c}80 \\
72\end{array}$ & $\begin{array}{c}106,309 \\
98,746\end{array}$ & \multirow{2}{*}{3,113} & \multirow{2}{*}{2,000} & \multirow{2}{*}{$\mathrm{H}_{\mathrm{o}}$ ditolak } \\
\hline
\end{tabular}

Dari analisis data kompetensi pengetahuan PPKn yang telah dilaksanakan didapatkan nilai rata-rata pada kelompok eksperimen $\bar{X}=80$.Pada analisis data kompetensi pengetahuan PPKn kelompok kontrol diperoleh nilai rata-rata $\bar{X}=72$. Berdasarkan hasil perhitungan data nilai kompetensi pengetahuan PPKn, menunjukkan bahwa rata-rata nilai kelompok eksperimen lebih dari rata-rata nilai kelompok kontrol.

Hasil hipotesis tentang kompetensi pengetahuan PPKn menunjukkan bahwa terdapat perbedaan yang signifikan antara siswa yang mengikuti pembelajaran Pair Checks berbasis Tat Twam Asi dengan siswa yang mengikuti pembelajaran konvensional pada siswa siswa kelas V di SDN Gugus I Kecamatan Selat Tahun Pelajaran 2019/2020.

Model pembelajaran Pair Checks berbasis Tat Twam Asi memiliki suatu pengaruh terhadap pembelajaran dikelas karena pembelajaran Pair Checks menuntut terjadinya interaksi, komunikasi dan kerjasama secara berkelompok. Pembentukkan kelompok ini agar suasana baru didalam kelas lebih menyenangkan dan membuat siswa belajar bekerja sama dengan pasangannya di dalam kelompok. Perilaku yang ditunjukkan siswa pada langkah ini yaitu, siswa lebih leluasa berkomunikasi dengan teman (pasangan kelompoknya) dalam menyelesaikan soal yang diberikan guru, dan juga dapat bertukar pikiran satu dengn lain mengenai pendapat masing-masing. Temuan tersebut sejalan dengan pendapat dari (Ibrahim, 2017) yang menyatakan pembelajaran kooperatif dapat membuat siswa lebih banyak melakukan aktivitas dalam pembelajaran berkelompok untuk menyelesaikan berbagai pokok permasalahan dalam pembelajaran.

Terkait dengan itu Tat Twam Asi juga mengajarkan tentang saling menghargai dan berinteraksi satu sama lain tanpa adanya perbedaan. Model Pembelajaran Pair Checks berbasis Tat Twam Asi dilakukan agar mampu saling menerima pendapat orang lain saat proses diskusi di kelas. Proses diskusi tentunya dapat menimbulkan perbedaan pendapat dalam menyelesaikan suatu permasalahan. Perbedaan yang terjadi harus dijadikan acuan menuju pemahaman akan pentingnya toleransi antar sesama. Maka dari itu diharapkan proses pembelajaran dan kompetensi pengetahuan siswa dapat meningkat. Model pembelajaran kooperatif Pair Checks merupakan model berkelompok yang dapat melatih siswa untuk saling berbagi tugas dan pengetahuan dengan temannya (Arsani, 2017). Model ini diawali dengan pembagian kelompok dimana masing-masing siswa berpasangan untuk menyelesaikan permasalahan dengan bergatian menjawab den mengecek jawaban pasangannya. Di dalam kelompok tersebut siswa bekerja sama menyelesaikan permasalahan-permasalahan yang diberikan. Dalam model ini guru hanya bertugas sebagai fasilisator dan siswa berperan aktif dalam menyelesaikan permasalahan yang diberikan dengan teman sekolompoknya (Mega, 2014). Dalam proses penyelesain masalah diamalkan ajaran Tat Twam Asi. Tat Twan Asi artinya aku adalah kamu, segala perilaku dan tindakan manusia diharapkan untuk tetap saling menghormati, menghargai, saling membantu, dan saling menjungjung rasa senasib sepenanggungan, rasa kebersamaan dan adanya sikap toleransi terhadap semua komponen kehidupan di dunia ini (Rismayani, 2013). Dengan adanya kerja sama di dalam kelompok dengan mengamalkan Tat Twam Asi siswa dapat menyelesaikan permasalahan dengan optimal dan kondusif yang nantinya akan berpengaruh terhadap kompetensi pengetahuan PPKn siswa yang meningkat dari sebelumnya.

Temuan hasil penelitian sebelumnya, yakni yang diajukan oleh (Kasminah, 2019) yang menyatakan bahwa terdapat perbedaan yang signifikan pada penguasaan kompetensi pengetahuan IPS yang mengikuti pembelajaran menggunakan model Pair Checks dengan kelompok yang mengikuti pembelajaran konvensional. Kemudian dengan penelitian (Yanti, 2014) menyatakan bahwa terdapat perbedaan yang signifikan pada kompetensi pengetahuan IPS siswa yang mengikuti pembelajaran berbasis Tat Twam Asi dengan siswa yang belajar menggunakan pembelajaran konvensional siswa. Kemudian sejalan pula dengan hasil penelitian yang dilakukan oleh (Selly Lindayani, 2019) menyatakan bahwa terdapat perbedaan yang 
signifikan pada kompetensi pengetahuan PPKn yang mengikuti pembelajaran bermuatan nilai karakter dengan siswa yang mengikuti pembelajaran konvensional siswa. Beberapa peneletian tersebut adalah terdapat persamaan dari pada variabel yang dikaji yaitu Model Pair Checks dan juga penerapan model dengan berbasis Tat Twam Asi sedangkan perbedaannya adalah terletak pada teknik sampling yang digunakan. Teknik sampling yang digunakan terdahulu diambil menggunakan simple random sampling, sedangkan dalam penelitian ini menggunakan teknik cluster random sampling. Berdasarkan hasil penelitian dan pembahasan tersebut dapat disimpulkan bahwa model pembelajaran Pair Checks berbasis Tat Twam asi berpengaruh terhadap kompetensi pengetahuan PPKn siswa kelas V SDN Gugus I Kecamatan Selat Tahun Pelajaran 2019/2020.

Berdasarkan hasil analisis, implikasi dalam penelitian ini adalah pemilihan cara yang tepat seperti pemakaian model pembelajaran yang baik serta dapat berpengaruh pada kompetensi pengetahuan PPKn yang diukur. Penelitian ini menyatakan bahwa pemilihan model pembelajaran Pair Checks berbasis Tat Twam Asi dapat digunakan dalam pembelajaran kompetensi pengetahuan PPKn. Hasil penelitian ini dapat dipergunakan sebagai salah satu alternative dalam memenuhi proses belajar-mengajar di sekolah dasar. Bersumber dari hasil penelitian yang diperoleh bahwa ditemukan dampak model Pair Checks berbasis Tat Twam Asi terhadap kompetensi pengetahuan PPKn siswa, sehingga dapat dipergunakan sebagai patokan bagi guru untuk membuat kegiatan belajar mengajar lebih variatif agar pembelajaran yang di harapkan tercapai. Model ini juga bisa digunakan oleh guru agar siswa tersebut tidak cepat merasa bosan dalam kegiatan belajar mengajar di sekolah dasar. Model Pair Checks berbasis Tat Twam Asi dapat membuat siswa termotivasi dalam belajar, pembelajaran menjadi menyenangkan dan mudah di pahamai, serta menjadikan siswa lebih aktif dan mandiri. Perbedaan tersebut menyatakan bahwa kelas eksperimen lebih unggul dan lebih baik hasilnya dapat dilihat melalui rata-rata kompetensi pengetahuan PPKn siswa dikelas eksperimen yang menggunakan model Pair Checks.

\section{SIMPULAN}

Berdasarkan hasil analisis data dan pembahasan, dapat disimpulkan bahwa model pembelajaran Pair Checks berbasis Tat Twam Asi berpengaruh terhadap kompetensi pengetahuan PPKn siswa kelas V SD. Adapun saran kepada phak-pihak terkait yaitu (1) Kepada guru, Bagi guru hendaknya mencoba model pembelajaran Pair Checks berbasis Tat Twam Asi untuk dapat mengembangkan kompetensinya dalam hal mengelola pembelajaran untuk mewujudkan kegiatan pembelajaran yang menyenangkan, efektif, dan mampu meningkatkan hasil belajar siswa. (2) Kepada kepala sekolah, Kepala sekolah dapat mengajak guru-guru untuk mengikuti seminar atau pelatihan dan menyarankan penggunaan model ini sebagai alternatif untuk meningkatkan hasil belajar siswa sehingga pada akhirnya kualitas pendidikan di sekolah tersebut meningkat. (3) Kepada peneliti lain, Kepada peneliti lain yang ingin melakukan penelitian selanjutnya hendaknya mengembangkan hasil penelitian dalam ranah afektif dan psikomotor untuk perbaikan serta penyempurnaan penelitian yang akan dijadikan sebagai referensi serta sumber informasi untuk penelitian selanjutnya.

\section{DAFTAR PUSTAKA}

Ahmad, F. 2016. "Penerapan Model Pembelajaran Kooperatif Tipe Pair Checks Dalam Meningkatkan Motivasi dan Hasil Belajar Terpadu Siswa Kelas VIIIA SMP Negeri 1 Tabulahan Kab. Mamasa". Jurnal Sainsmat, Vol.2 (Halaman 137-142).

Ananda, R. 2018. "Peningkatan Pembelajaran PKn Dengan Penerapan Metode Role-Playing Siswa Kelas II SDN 003 Bangkinang Kota". Jurnal Basicedu, Volume 2, Nomor 1 (halaman 34-42).

Arikunto, Suharsimi. 2015. Dasar-Dasar Evaluasi Pendidikan. Jakarta: Bumi Aksara.

Arni Rahayuni, N. P., Sri Asri, I. G. A. A., \& Suniasih, N. W. (2018). Pengaruh Model Pembelajaran Pair Check Berbasis Penilaian Kinerja Terhadap Kompetensi Pengetahuan PKn Siswa Kelas IV. Mimbar Ilmu.

Arsani, N. K., Suarni, N. K., \& Kusmaryatni, N. (2017). Pengaruh Model Pembelajaran SAVI 
Berbantuan Gerakan Literasi Sekolah terhadap Hasil Belajar PKn Siswa Kelas IV. E-Jounal $P G S D$.

Atmaja, Nada., dkk. 2011. Etika Agama Hindu. Surabaya :Paramita.

Bagja, S. W., \& Yuliana, D. (2019). Penerapan Model Pembelajaran Discovery Learning Meningkatkan Motivasi dan Hasil Belajar Pendidikan Kewarganegaraan 1. Jurnal Rontal Keilmuan PKn.

Erman. 2008. "Model Belajar dan Pembelajaran Berorientasi Kompetensi Siswa". Jurnal Pendidikan dan Budaya, Volume 5 Nomor 2 (halaman 1-31).

Ermavianti, D., \& Sulistyorini, W. (2016). Model Pembelajaran Kooperatif Tipe Pair Check untuk Membangun Keterampilan Bertanya Produktif Siswa. Jurnal Pendidikan Teknologi Dan Kejuruan. https://doi.org/10.21831/jptk.v23i1.9350

Handayani, R. D., \& Yanti, Y. (2017). Pengaruh Model Pembelajaran Kooperatif Tipe Think Pair Share Terhadap Hasil Belajar PKn Siswa di Kelas IV MI Terpadu Muhammadiyah Sukarame Bandar Lampung. Jurnal Pendidikan Dan Pembelajaran Dasar.

Ibrahim. 2017. "Pengaruh Model Pembelajaran Aktif Konvensional (Ceramah) Dengan Cooperatif (Make-A Match) Untuk Meningkatkan Hasil Belajar Pendidikan Kewarganegaraan". Jurnal Ilmu Pendidikan Sosial, sains, dan Humaniora, Vol.3, No.2 (Halaman 199-211).

Ihsan. 2017. "Kecenderungan Global dalam Proses Pembelajaran Pendidikan Pancasila Dan Kewarganegaraan Di Sekolah". Jurnal Pancasila dan Kewarganegaraan, Vol.2, No.2 (Halaman 49-58).

Kasminah, K. (2019). Penerapan Model Pembelajaran Kooperatif Tipe Make A Match Untuk Meningkatkan Hasil Belajar PKn. Jurnal Pajar (Pendidikan Dan Pengajaran). https://doi.org/10.33578/pjr.v3i6.7886

Kementrian Riset, Teknologi, dan Pendidikan Tinggi Repbulik Indonesia. 2016. Pendidikan Kewarganegaraan Pendidikan Kewarganegaraan untuk Perguruan Tinggi. Jakarta : Ristekdikti.

Kristin, F. 2016. "Efektifitas Model Pembelajaran Kooperatif Tipe STAD Ditinjau dai Hasil Belajar IPS Siswa Kelas 4 SD”. Jurnal Scholaria, Volume 6, Nomor 2 (halaman 74-79).

Kunandar. 2015. Penilaian Autentik (Penilaian Hasil Belajar Peserta Didik Berdasarkan Kurikulum 2013) Suatu Pendekatan Praktis Disertai dengan Contoh. Jakarta: Rajawali Pers.

Mardika, 2017 "Pengaruh Model Pembelajaran Think Talk Write Terhadap Keterampilan Membaca Bahasa Indonesia Siswa Kelas III SD. Mimbar PGSD, Volume 5, Nomor 2.

Mega, N. L. G., Dewi, P., Asri, I. G. A. A. S., \& Wiyasa, I. K. N. (2014). Model Pembelajaran Take and Give Berbantuan Media Grafis Terhadap Hasil Belajar PKn SD. Mimbar PGSD Universitas Pendidikan Ganesha.

Miswandi, M. (2018). Peningkatan Hasil Belajar PKN SD melalui Stategi Crossword Puzzle. Jurnal Pendidikan : Riset Dan Konseptual. https://doi.org/10.28926/riset_konseptual.v2i3.66

Peraturan Menteri Pendidikan dan Kebudayaan Republik Indonesia Nomor 35 Tahun 2018 tentang Perubahan atas Peraturan Menteri Pendidikan dan Kebudayaan.2018. Jakarta : Menteri Pendidikan Dan Kebudayaan Republik Indonesia. diakses pada tanggal: 1 juni 2020.

Prakoso, G. A. (2015). Keefektifan Model Pembelajaran Pair Check Dan Numbered-Heads Together (NHT) Ditinjau dari Hasil Belajar dalam Pembelajaran IPS Kelas 4 SDN Gugus Mahesa Jenar Ambarawa. Scholaria : Jurnal Pendidikan Dan Kebudayaan.

Puspita, dkk. 2018. Pengaruh Model Pembelajaran Kooperatif Tipe Pair Checks Terhadap penguasaan Kompetensi Pengetahuan Ips Siswa Kelas Iv Sd Gugus Ii Kuta Selatan Tahun Ajaran 2017/2018. Universitas Pendidikan Ganesha, Volume 1, Nomor 1. Tersedia pada ejournal.undiksha.ac.id (diakses pada tanggal 22 Oktober 2019).

Rismayani, N. L. (2013). Penerapan Model Pembelajaran Discovery Learning Untuk Meningkatkan Hasil Belajar PKN Siswa. Jurnal Pendidikan Kewarganegaraan Undiksha Indexed.

Selly Lindayani, N. P., Putra, M., \& Manuaba, I. B. S. (2019). Pengaruh Model Pembelajaran Value Clrification Technique Bermuatan Nilai Karakter Terhadap Kompetensi Pengetahuan 
PPKn. Thinking Skills and Creativity Journal. https://doi.org/10.23887/tscj.v2i2.20709

Shoimin, Aris. 2014. 68 Model Pembelajaran Inovatif dalamKurikulum 2013. Yogyakarta: Ar-Ruzz Media.

Sugiyono. 2016. Metode Penelitian Pendidikan. Bandung: ALFABETA.

Sumarni, Harun, A. H., \& Imran. (2014). Penerapan Metode Diskusi Untuk Meningkatkan Hasil Belajar Siswa Kelas IV Sekolah Dasar Kecil Toraranga Pada Mata Pelajaran PKn Pokok Bahasan Sistem Pemerintahan. Jurnal Kreatif Tadulako Online.

Susanto, A. (2013). Teori Belajar Dan Pembelajaran Di Sekolah Dasat. In Biomass Chem Eng.

Susanto, A. 2012. Teori Pembelajaran di Sekolah Dasar. Jakarta: Prenadamedia Group.

Undang-Undang Republik Indonesia Nomor 20 Tahun 2003 tentang Sistem Pendidikan Nasional. 2003. Jakarta: Presiden Republik Indonesia. diakses pada tanggal: 3 Oktober 2019

Wesi Kusuma, I. G. L. A. (2018). Implementasi Ajaran Tat Twam Asi Terhadap Mahasiswa Penyandang Tunanetra Di IHDN Denpasar. Jurnal Penelitian Agama Hindu.

Yanti, K. I. (2014). PENERAPAN MODEL PEMBELAJARAN KOOPERATIF TIPE STAD UNTUK MENINGKATKAN HASIL BELAJAR PKn SISWA. Jurnal Pendidikan Kewarganegaraan.

Yulia Citra, A. (2018). Pengaruh Model Pembelajaran Kooperatif Tipe Pair Check. Jurnal Penelitian Pendidikan Guru Sekolah Dasar. 